\title{
Effects of supplementation of xylanase, phospholipase or combination of both to a wheat- based diet on digestive function in early-weaned piglets
}

\author{
V. Sileikiene ${ }^{1,2}$, G. Diebold ${ }^{1}$, M. Tafaj ${ }^{1}$ and R. Mosenthin ${ }^{1,3}$ \\ ${ }^{I}$ Institute of Animal Nutrition, University of Hohenheim \\ D-70593 Stuttgart, Germany \\ ${ }^{2}$ Department of Animal Nutrition, Lithuanian Veterinary Academy \\ 3000 Kaunas, Lithuania
}

(Received 29 March 2005; revised version 14 September 2005; accepted 6 January 2006)

\begin{abstract}
The effect of enzyme supplementation was studied in a balanced three-period ( 3 x 13 days) crossover trial with 16 male piglets weaned on day 11 post-natum. On days 15 and 16 of age the piglets were fitted with a simple T-cannula at the distal ileum. Starting on day 21 post-natum, piglets were fed the basal diet $(22.1 \% \mathrm{CP}$ and $14.5 \mathrm{MJ} \mathrm{ME} / \mathrm{kg}$ as fed) without or with the addition of xylanase (endo-1,4- $\beta$-xylanase, EC 3.2.1.8) at a level of $5600 \mathrm{EXU} / \mathrm{kg}$ (as fed) or phospholipase (phospholipase A2, EC 3.1.1.4) at a level of $1000 \mathrm{IU} / \mathrm{kg}$ (as fed), or a combination of both. Activities of maltase, lactase, leucine aminopeptidase (LAP), lipase and $\alpha$-amylase were measured in ileal digesta. The supplementation with exogenous feed enzymes had no significant $(\mathrm{P}>0.05)$ effect on the activities of maltase, LAP, lipase and $\alpha$-amylase. The activity of lactase tended $(\mathrm{P}=0.1)$ to be higher in piglets fed the diet supplemented with the combination of both enzymes compared to the basal diet. In conclusion, the addition of exogenous feed enzymes had only minor effects on the activity of piglets' own enzymes in the chyme entering the hindgut.
\end{abstract}

KEY WORDS: early-weaned piglets, brush border enzymes, pancreatic enzymes, xylanase, phospholipase

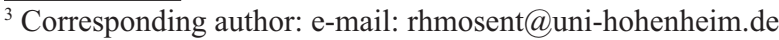




\section{INTRODUCTION}

The post-weaning period of piglets is generally associated with major stresses such as a separation from the sow, a new environment and changes in diet composition. Due to these stressors marked changes occur in the morphohistological structure in the small intestine of piglets, such as atrophy of villous, crypt hyperplasia, and a decline in the activity of brush-border enzymes (Pluske et al., 1997; Pluske, 2001). Moreover, during the first 3-7 days after weaning, the secretion of pancreatic enzymes is depressed by $30-75 \%$ (Le Huërou-Luron and Guilloteau, 1999). Thus, undigested nutrients may accumulate in the distal part of the gastro-intestinal tract and facilitate the rapid proliferation of pathogenic Escherichia coli, which is frequently associated with the occurrence of diarrhoea during the post-weaning period (Botermans et al., 1999).

One approach to overcome these problems is to supplement pig diets with exogenous feed enzymes in an attempt to aid the digestion and absorption of nutrients (Jensen et al., 1994). According to previous studies (Inborr et al., 1993; Diebold et al., 2004), the inclusion of feed enzymes, such as $\beta$-glucanase and xylanase, in diets for weaned piglets improved the ileal digestibility of nutrients, especially of crude protein. However, only few studies have been focused so far on the question if exogenous feed enzymes may have an impact on the pig's own secretion of endogenous enzymes (Inborr et al., 1994; Jensen et al., 1994, 1996, 1998). Conflicting results have been reported. In some studies (Jensen et al., 1994, 1996) supplementation of $\beta$-glucanase to barley-based diets for piglets caused an increase in the secretion of pancreatic proteolytic enzymes (i.e. chymotrypsin). However, Jensen et al. (1998), who measured the activity of pancreatic enzymes in digesta of different segments of the small intestine and pancreatic tissue, obtained no effect of exogenous feed enzymes on the activity of pancreatic enzymes. Other authors (e.g., Inborr et al., 1994) even report that feed enzymes may depress the activity of pancreatic enzymes measured in digesta obtained from different segments of the small intestine.

The aim of the present study was to investigate the effects of the supplementation of a wheat-based diet with xylanase or phospholipase or a combination of these feed enzymes on the secretion of digestive enzymes in weaned piglets.

\section{MATERIAL AND METHODS}

\section{Animals and housing}

The piglets used in the experiment were obtained from a production herd of Unterer Lindenhof Research Station (University of Hohenheim, Germany), and housed individually in metabolic crates. Each crate was equipped with an infrared heating lamp and a low-pressure drinking nipple, which allowed free access to water. 
The piglets used in the study were cared for in accordance with the guidelines issued by the German regulation for care and treatments of animals (Lorz and Metzger, 1999). The experimental protocols were approved by the German Ethical Commission.

\section{Design and experimental procedures of experiments}

The effect of exogenous enzyme supplementation was investigated in a balanced three-period ( 3 x 13 d) crossover design. Sixteen male piglets (German Landrace $\mathrm{x}$ Piétrain) were weaned at 11 days of age. On days 15 and 16 post-natum, with an average body weight (BW) of $4.4 \pm 0.6 \mathrm{~kg}$, the piglets were surgically fitted with a simple T-shaped cannula at the distal ileum (Li et al., 1993). After surgery, they received a commercial milk-replacer with small amounts of the control diet for 5 days. Starting on day 21 post-natum, the piglets were fed a basal diet that contained $22.1 \% \mathrm{CP}$ and $14.5 \mathrm{MJ} \mathrm{ME} / \mathrm{kg}$ (Table 1).

Table 1. Diet formulation and calculated nutrient and energy content of the basal diet ${ }^{1}$

\begin{tabular}{lc}
\hline Item & $\%$ as fed basis \\
\hline Ingredients & 60.20 \\
wheat & 3.00 \\
wheat bran & 5.00 \\
soyabean meal (full fat) & 10.34 \\
soyabean protein isolate & 5.50 \\
tallow & 6.80 \\
skim milk powder & 5.80 \\
sucrose & 0.47 \\
monocalcium phosphate & 0.37 \\
calciumcarbonate & 0.24 \\
lysine HCl & 0.07 \\
D,L-methionine & 0.01 \\
threonine & 0.20 \\
titanium oxide & 2.00 \\
vitamin/mineral premix ${ }^{2}$ & \\
& \\
Nutrient and energy content & 89.80 \\
dry matter & 14.54 \\
ME MJ/kg & 24.20 \\
crude protein & 0.82 \\
Ca & 0.44 \\
P, available &
\end{tabular}

${ }^{1}$ formulated according to NRC requirements (1998)

${ }^{2}$ the vitamin and mineral premix provided the following per kg of diet: g: Ca 5, P 1.3; mg: Fe 100, $\mathrm{Zn} \mathrm{100,} \mathrm{Cu} \mathrm{23,} \mathrm{I} \mathrm{1.2,} \mathrm{Se} \mathrm{0.3,} \mathrm{choline} \mathrm{750,} \mathrm{riboflavin} \mathrm{4,} \mathrm{niacin} \mathrm{22,} \mathrm{panthotenic} \mathrm{acid} \mathrm{15,} \mathrm{vitamin} \mathrm{B}_{12}$ 0.02 ; vit. IU: A 8,000, $\mathrm{D}_{3} 1,000$, E 60 
The experimental diets were supplemented either with xylanase (endo-1,4$\beta$-xylanase, EC 3.2.1.8) at a level of $5600 \mathrm{EXU} / \mathrm{kg}$ (as fed) or phospholipase (phospholipase A2, EC 3.1.1.4) at a level of $1000 \mathrm{IU} / \mathrm{kg}$ (as fed), or a combination of both. The level of enzyme supplementation was based on manufacturer's recommendations (BASF AG; Ludwigshafen, Germany). Piglets were fed twice daily $(08.00$ and $20.00 \mathrm{~h})$ at an average rate of $5 \%$ of BW (max 7\% BW). Feed intake was recorded daily. BW was recorded at the beginning of each period and at the end of the trial.

\section{Digesta collection}

Ileal digesta were collected twice daily, from 08.00 to $09.00 \mathrm{~h}$ and from 13.00 to $14.00 \mathrm{~h}$ on day 11 of each experimental period. Ileal digesta were collected using plastic tubing which was attached to the barrel of the cannula by aid of elastic bands. The tubing was removed and replaced as soon as it was partially filled with digesta. Digesta samples were immediately frozen in liquid nitrogen following collection and stored at $-75^{\circ} \mathrm{C}$ until analyses.

\section{Chemical analyses}

Digesta samples for all analyses were pooled within each animal and centrifuged $\left(60 \mathrm{~min}\right.$ at $3{ }^{\circ} \mathrm{C} ; 21780 \times \mathrm{g}$ ), except for the determination of $\alpha$-amylase activity. The protein content $(\mathrm{mg} / \mathrm{ml})$ and activity of enzymes $(\mathrm{U} / \mathrm{l}$ or $\mathrm{U} / \mathrm{ml})$ were determined in aliquot parts (supernatant) either directly (LAP, lipase and protein) or, for lactase and maltase, after the removal of endogenous glucose by DEAE anion exchange columns (Raab et al., 1998). The protein content of digesta $(\mathrm{mg} / \mathrm{ml})$ was determined according to Bradford (1976). Activities of maltase ( $\alpha$-glucosidase, EC 3.2.1.20) and lactase ( $\beta$-galactosidase, EC 3.2.1.23) were determined according to the method of Dahlqvist (1968) and Bergmeyer and Bernt (1974) as described by Schad (2002). Leucine aminopeptidase (Leucine arylamidase, LAP, EC 3.4.11) activity was determined with a commercial photometric test kit (Boehringer/ Mannheim LAP, No 204323), using L-leucine p-nitroanilin as a substrate as described by Schad (2002). The activity of $\alpha$-amylase (1,4- $\alpha$-D-glucanehydrolase, EC 3.2.1.1) was measured using the Phadebas ${ }^{\circledR}$ amylase reagent (Pharmacia and Upjohn Diagnostics, Freiburg, Germany) as a substrate as described by Kienzle (1988). The lipase activity (triacylglycerol acylhydrolase, EC 3.1.1.3) was analysed using 1,2-o-dilauryl-rac-glycero-3-glutar acid-(6-methylresorutin)-ester as substrate. For dry matter determination digesta was dried at $105^{\circ} \mathrm{C}$ for approx. $4 \mathrm{~h}$ to constant weight. 


\section{Statistical analysis}

The effect of exogenous feed enzymes on the secretion of digestive enzymes was tested by one-way analysis of variance using the GLM-procedure of SAS (SAS Institute, 1999, Release 8.2). Results are expressed as least squares means with the standard error of the mean $( \pm$ SEM). Differences between treatments were considered to be significant at $\mathrm{P} \leq 0.05$; trends were set at $\mathrm{P} \leq 0.10$.

\section{RESULTS AND DISCUSSION}

The effects of supplementation of xylanase or phospholipase, or a combination of both enzymes on endogenous enzyme activities in ileal digesta of weaned piglets are shown in Table 2. There was no significant effect $(\mathrm{P}>0.05)$ of the supplementation with xylanase on the activities of brush-border enzymes (Table 2). These results agree, in part, with those by Li et al. (2004) who

Table 2. Effect of enzyme supplementation on endogenous enzyme activities in ileal digesta of weaned piglets ${ }^{1}$

\begin{tabular}{lcccc}
\hline \multirow{2}{*}{ Item } & Basal & \multicolumn{3}{c}{ Basal diet plus } \\
\cline { 3 - 5 } & diet & xylanase & phospholipase & both enzymes \\
\hline Lactase, $\mathrm{mU} / \mathrm{mg}$ protein & $14.9 \pm 2.5$ & $17.8 \pm 2.5$ & $14.4 \pm 2.5$ & $20.5 \pm 2.6 \dagger$ \\
Maltase, $\mathrm{mU} / \mathrm{mg}$ protein & $43.9 \pm 7.6$ & $62.3 \pm 7.2$ & $56.0 \pm 7.3$ & $65.4 \pm 8.2$ \\
LAP ${ }^{2}, \mathrm{U} / \mathrm{mg}$ protein & $1.1 \pm 0.2$ & $1.3 \pm 0.2$ & $1.4 \pm 0.2$ & $1.3 \pm 0.2$ \\
$\alpha$-amylase, U/g DM chyme & $775.4 \pm 136.0$ & $663.3 \pm 149.8$ & $686.4 \pm 135.5$ & $875.0 \pm 138.2$ \\
Lipase, $\mathrm{U} / \mathrm{mg}$ protein & $400.3 \pm 70.4$ & $295.1 \pm 70.8$ & $367.0 \pm 73.5$ & $323.8 \pm 72.0$ \\
\hline${ }^{1}$ results are expressed as least squares means & with the standard error of the mean $( \pm \mathrm{SEM})$. \\
Differences compared to the control diet within rows are marked $\dagger$ for tendencies $(\mathrm{P} \leq 0.10)$ \\
${ }^{2}$ leucine aminopeptidase
\end{tabular}

reported that the supplementation of pig diets based on barley with both xylanase and $\beta$-glucanase caused a significant increase in activity of $\gamma$-glutamyl transpeptidase in the jejunal mucosa only, whereas activities of disaccharidases, including maltase and lactase, were not significantly changed. Moreover, the authors showed that exogenous non starch polysaccharides (NSP) degrading enzymes decreased significantly activities of pancreatic enzymes, including $\alpha$-amylase and lipase, in digesta obtained from the distal part of the duodenum. However, in the present study the supplementation with xylanase did not significantly influence the activities of pancreatic enzymes in the small intestinal content (Table 2). This is in partial agreement with Inborr et al. (1994) and Jensen et al. (1998). Jensen et al. (1998) reported that $\beta$-glucanase supplementation did not significantly affect 
the activities of lipase and $\alpha$-amylase measured in the content of distal small intestine and pancreatic tissue. Inborr et al. (1994) found that the supplementation of barley-based diets with $\beta$-glucanase caused a negligible decrease $(\mathrm{P}<0.08)$ in the activity of $\alpha$-amylase in the intestinal digesta of piglets only.

In the present study, the supplementation with phospholipase did not cause significant changes in activities of endogenous enzymes, only slightly numerical increases in activities of LAP and maltase were observed. It must be emphasized that no reports have been published so far on the effect of the phospholipase supplementation on the activity of digestive enzymes in piglets. Previously, Diebold et al. (2004) observed that the supplementation with phospholipase to a wheat based diet for piglets improved the ileal digestibility of crude protein $(\mathrm{P}<0.05)$. Moreover, the authors reported that the supplementation with a combination of both xylanase and phospholipase improved the ileal digestibility of crude protein and crude fibre. A slight increase in activities of maltase, lactase $(\mathrm{P}=0.1)$ and $\alpha$-amylase in piglets fed a diet supplemented with a combination of both xylanase and phospholipase in the present study support, in part, the results reported by Diebold et al. (2004). These authors observed also a slight increase in ileal crude fat digestibility upon dietary supplementation with both xylanase and phospholipase. Since lipase activity, based on the results of the present study, was not affected, this improvement in fat digestibility has to be attributed to exogenous xylanase and phospholipase supplementation.

The results of period effect (i.e. age effect) on the enzymatic activity are summarized in Table 3. No significant age-dependent changes $(\mathrm{P}>0.05)$ could be observed for lactase activity. This is in agreement, in part, with recent studies of Marion et al. (2001) and Sileikiene et al. (2002). In the study of Sileikiene et al. (2002), performed on piglets weaned at day 18 post-natum and fed a solid diet starting from day 33 , lactase activity slightly declined during the first 4 days after transition from a liquid milk-replacer to a solid diet containing skim milk powder and remained constant up to day 46 post-natum. Marion et al. (2001) found similar activities of lactase in 10-, 14- and 21-day old weaned piglets. This might be due to the presence of lactose in the diet.

Table 3. Effect of age on endogenous enzyme activities in ileal digesta of weaned piglets ${ }^{1}$

\begin{tabular}{lccc}
\hline Item & Period I & Period II & Period III \\
\hline Lactase, mU/mg protein & $16.6 \pm 3.3$ & $18.7 \pm 2.7$ & $15.4 \pm 1.8$ \\
Maltase, mU/mg protein & $50.9 \pm 7.2$ & $70.5 \pm 8.0$ & $49.5 \pm 6.1$ \\
LAP $^{2}, \mathrm{U} / \mathrm{mg}$ protein & $1.8 \pm 0.2$ & $0.8 \pm 0.1^{*}$ & $1.2 \pm 0.1^{*}$ \\
$\alpha$-amylase, U/g DM chyme & $845.2 \pm 238.2$ & $770.5 \pm 79.6$ & $634.4 \pm 94.6$ \\
Lipase, U/mg protein & $296.5 \pm 58.3$ & $429.9 \pm 68.6$ & $313.2 \pm 79.4$ \\
\hline
\end{tabular}

${ }^{1}$ results are expressed as least squares means with the standard error of the mean $( \pm \mathrm{SEM})$. Differences compared to the Period I within the same row are marked * for $\mathrm{P} \leq 0.05$

${ }^{2}$ leucine aminopeptidase 
Although classically maltase activity increased continuously with age (Le Huërou-Luron et al., 2001; Marion et al., 2001; Sileikiene et al., 2002), in the present study no age-dependent increase $(\mathrm{P}>0.05)$ in the activity of maltase could be observed. Moreover, the activity of LAP decreased in Period II $(\mathrm{P}<0.02)$ and III $(\mathrm{P}<0.03)$ compared to Period I and tended to recover in Period III $(\mathrm{P}>0.06)$ (Table 3). Studies carried out to investigate the development of peptidase in weaned piglets (Marion et al., 2001; Le Huërou-Luron, 2002; Sileikiene et al., 2002; Hedemann et al., 2003) led us to assume that the development is specific for different peptidases. For example, Hedemann et al. (2003) reported in a study performed on piglets weaned at four weeks of age that the activity of peptidases on day 9 post-weaning generally did not differ from that observed on the day of weaning. Sileikiene et al. (2002) have shown that the LAP activity after increase during the first 4 days after transition from a liquid milk-replacer to a solid diet slightly dropped in the following days and remained constant up to day 46 postnatum. According to Marion et al. (2001) and Le Huërou-Luron (2002) the specific activity of aminopeptidase A does not change after weaning at 7 days of age and that of aminopeptidase $\mathrm{N}$ increases during the 3 days after weaning and remains constant up to 2 weeks after weaning. A tendency for a post-weaning recovery in the activity of aminopeptidase $\mathrm{N}$ was observed only in the jejunum of piglets 5 weeks after weaning (Le Huërou-Luron, 2002).

The age did not affect $(\mathrm{P}>0.05)$ the activities of pancreatic enzymes in the present study (Table 3). Previously, it was demonstrated that lipase activity decreased in the first week after transition from a liquid milk-replacer to a solid diet and remains constant in the following days. Moreover, it was observed that the activity of $\alpha$-amylase increased in the first 3 days after weaning and recovered to the level observed before weaning in the following days (Sileikiene et al., unpublished data). Similarly, Marion et al. (2001) found that in piglets, the activity of lipase decreased after weaning at 7 days of age during the 3 days thereafter, and remained constant up to 2 weeks after weaning.

\section{CONCLUSIONS}

In conclusion, the results indicate that the supplementation of exogenous feed enzymes did not affect the activity of pancreatic enzymes. It seems that the inclusion of exogenous enzymes in piglet's diets could enhance the secretion of brush-border enzymes only. Moreover, the lack of age effect on the activity of pancreatic and brush-border enzymes indicates a rapid functional maturation of the intestine in early weaned piglets. 


\section{REFERENCES}

Bergmeyer H.U., Bernt E., 1974. Bestimmung mit Glucose-Oxidase und Peroxidase. In: H.U. Bergmeyer, K. Gawehn (Editors). Methoden der enzymatischen Analyse. 3. erw. Auflage. Weinheim Verlag Chemie, pp. 1250-1259

Botermans J.A.M., Svendesen J., Svendsen L.S., Pierzynowski S.G., 1999. The exocrine pancreas in pig growth and performance. In: S.G. Pierzynowski, R. Zabielski (Editors). Biology of the Pancreas in Growing Animals. Elsevier, Amsterdam, pp. 395-408

Bradford M.M., 1976. A rapid and sensitive method for the quantitation of microgram quantities of protein utilizing the principle of protein-dye binding. Anal. Biochem. 72, 248-254

Dahlqvist A., 1968. Assay of intestinal intestinal disaccharidases. Anal. Biochem. 22, 99-107

Diebold G., Mosenthin R., Piepho H.-P., Sauer W.C., 2004. Effect of supplementation of xylanase and phospholipase to a wheat-based diet for weaning pigs on nutrient digestibility and concentrations of microbial metabolites in ileal digesta and feces. J. Anim. Sci. 82, 2647-2656

Hedemann M.S., Højsgaard S., Jensen B.B., 2003. Small intestinal morphology and activity of intestinal peptidases in piglets around weaning. J. Anim. Physiol. Anim. Nutr. 87, 32-41

Inborr J., Jensen B.B., Bach Knudsen K.I., Jensen S.M., Jakobsen M.K., 1994. Enzyme supplementation of barley-based pig starter diets improves the efficiency of digestion by changing the conditions in the gastrointestinal tract. In: W.-B. Souffrant, H. Hagemeister (Editors). Proceedings of VIth International Symposium on Digestive Physiology in Pigs. Bad Doberan (Germany), EAAP Publication No. 80, Vol. 2, pp. 352-354

Inborr J., Schmitz M., Ahrens F., 1993. Effect of adding fibre and starch degrading enzymes to a barley/wheat based diet on performance and nutrient digestibility in different segments of the small intestine of early weaned pigs. Anim. Feed Sci. Tech. 44, 113-127

Jensen M.S., Bach Knudsen K.E., Inborr J., Jakobsen K., 1998. Effect of $\beta$-glucanase supplementation on pancreatic enzyme activity and nutrients digestibility in piglets fed diets based on hulled and hulless barley varieties. Anim. Feed Sci. Tech. 72, 329-345

Jensen M.S., Jakobsen K., Thaela M.-J., Pierzynowski S.G., 1994. Effect of enzyme supplementation of barley-based pig starter diet on the exocrine pancreatic secretion. In: W.-B. Souffrant, H. Hagemeister (Editors). Proceedings of VIth International Symposium on Digestive Physiology in Pigs. Bad Doberan (Germany), EAAP Publication No. 80, Vol. 2, pp. 319-321

Jensen M.S., Thaela M.-J., Pierzynowski S.G., Jakobsen K., 1996. Exocrine pancreatic secretion in young pigs fed barley-based diets supplemented with $\beta$-glucanase. J. Anim. Physiol. Anim. Nutr. 75, 231-241

Kienzle E., 1988. Enzymaktivität in Pancreas, Darmwand und Chymus des Hundes in Abhängigkeit von Alter und Futterart. J. Anim. Physiol. Anim. Nutr. 60, 276-288

Le Huërou-Luron I., 2001. Are the activities of intestinal peptidases age- and diet-dependent in piglets? In: J.E. Lindberg, B. Ogle (Editors). Digestive Physiology of Pigs. CABI, Uppsala (Sweden), pp. 20-22

Le Huërou-Luron I., 2002. Production and gene expression of brush border disaccharidases and peptidases during development in pigs and calves. In: R. Zabielski, P.C. Gregory, B. Weström (Editors). Biology of the Intestine in Growing Animals. Elsevier, Amsterdam, pp. 491-513

Le Huërou-Luron I., Guilloteau P., 1999. Effects of age and food on exocrine pancreatic function and some regulatory aspects. In: S.G. Pierzynowski, R. Zabielski (Editors). Biology of the Pancreas in Growing Animals. Elsevier, Amsterdam, pp. 213-229

Li S., Sauer W.C., Fan M.Z., 1993. The effect of dietary crude protein level on amino acid digestibility in early weaned pigs. J. Anim. Physiol. Anim. Nutr. 70, 26-37 
Li W.-F., Feng J., Xu Z.-R., Yang C.-M., 2004. Effects of non-starch polysaccharides enzymes on pancreatic and small intestinal digestive enzyme activities in piglet fed diets containing high amounts of barley. World J. Gastroenterol. 10, 856-859

Lorz A., Metzger E., 1999. Tierschutzgesetz: Tierschutzgesetz mit allgemeiner Verwaltungsvorschrift, Rechtsverordnungen und europäischen Übereinkommen; Kommentar. München, Beck, 5. neubearb. Auflage

Marion J., Le Huërou-Luron I., Thomas F., Rome V., Le Dividich J., 2001. Weaning of supernumerary piglets at 7 days of age: Effects on digestive function-preliminary results. In: J.E. Lindberg, B. Ogle (Editors). Digestive Physiology of Pigs. CABI, Uppsala (Sweden), pp. 34-36

NRC, 1998. Nutrient Requirements of Swine. 10. Edition. National Academy Press. Washington, DC

Pluske J.R., 2001. Morphological and functional changes in the small intestine of the newlyweaned pig. In: A. Piva, K.E. Bach Knudsen, J.E. Lindberg (Editors). Gut Environment of Pigs. University Press. Nottingham (UK), pp. 1-27

Pluske J.R., Hampson D.J., Williams I.H., 1997. Factors influencing the structure and function of the small intestine in the weaned pigs: a review. Livest. Prod. Sci. 51, 215-236

Raab S., Leiser R., Kemmer H., Claus R., 1998. Effects of energy and purines on proliferation, differention, and apoptosis in the small intestine of the pig. Metabolism 47, 1105-1111

SAS, 1999. SAS/STAT Software: Changes and Enhancements through Release 8.2. SAS Institute Inc., Cary, NC

Schad A., 2002. Einfluss einer Spermin- oder Nukleotidzulage auf Aminkonzentrationen und Enzymaktivitäten im Dünndarm von Ferkeln. PhD. Thesis, University of Hannover (Germany)

Sileikiene V., Mosenthin R., Claus R., Gutscher M., Tafaj M., Gruzauskas R., 2002. Entwicklung der Dünndarmfunktion beim Ferkel während der Umstellung von der flüssigen auf die feste Nahrungsform. Vet. Med. a. Z. 20, 113-119 